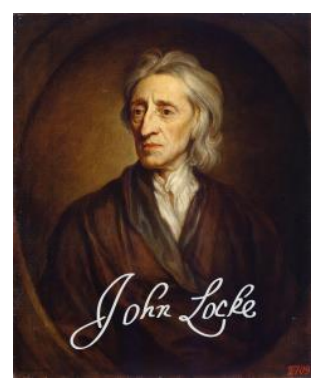

LOCKE STUDIES

Vol. 17

https://doi.org/10.5206/ls.2017.885 | ISSN: 2561-925X

Originally published: 2017

Published online: 01 JANUARY 2019

(C) Locke Studies, 2017

\title{
Locke's Political Theology and the 'Second Treatise'
}

\author{
JOANNE TETLOW (MARYMOUNT UNIVERSITY)
}

Recommended citation:

Tetlow, Joanne. "Locke's Political Theology and the 'Second Treatise'." Locke Studies 17 (2017): 197232. https://doi.org/10.5206/ls.2017.885.

For more information about this article:

see this article's webpage.

Locke Studies is published by The John Locke Society.

This is an open access article published under the terms of the Creative Commons AttributionNonCommercial-ShareAlike 4.0 International license, which permits use, distribution and reproduction in any medium, provided the original work is properly cited and shared under the original license. 


\title{
LOCKE'S POLITICAL THEOLOGY AND THE 'SECOND TREATISE'
}

\author{
JOANNE TETLOW
}

\section{§1. Introduction}

It is a contested issue, particularly among modern and postmodern scholars, whether political theory requires a foundation-some set of background assumptions (about the nature of existence, the nature of agency, what is of value in human life and so forth) that is fundamental to and presupposed absolutely by it. Andrew Vincent, in his book The Nature of Political Theory (2004), analyzes different types of foundations based on the assumption that they are necessary and ubiquitous. He believes this is so because as a finite being, without absolute certainty and objective knowledge, man naturally seeks a foundation, which in a comprehensive and complete sense eludes him. In other words, political theory is permanently in search of 'foundational arguments' that 'are intrinsically unresolvable'. ${ }^{1}$ According to Vincent, '[w]e may not be able to identify absolutes, but neither can we avoid foundationalism'. ${ }^{2}$ It is the nature of our being, he suggests, that we continually ask questions that cannot be absolutely resolved. Vincent takes it to follow that the foundations upon which political theory relies are and must be 'ordinary and multiversal, rather than extraordinary and universal'. Lacking absolute certainty, we are confronted with 'multiple foundational problems and answers, which are not finished'. This state of affairs, he suggests, 'is deeply irritating for some, but is quite normal and ordinary for humanity, and should become normal and ordinary within political theory.' 3

John Locke would have agreed about the need of a foundation

\footnotetext{
${ }^{1}$ Andrew Vincent, The Nature of Political Theory (Oxford, 2007), 325.

${ }^{2}$ Ibid.

${ }^{3}$ Ibid.
} 
for politics; however, in the second of his Two Treatises of Government (1690), and in other works, he does not countenance multiple foundations but posits instead what Vincent claims cannot be had-one foundation which demands and delivers singular, certain, objective, comprehensive, and universal answers to fundamental political and moral questions. The claim to absolute certainty is what might strike modern and postmodern thinkers as too dogmatic; the form in which that claim has been understood to have been laid ${ }^{4}$-as an assertion of the truth of Christian revelation - is what might strike them as too parochial, even if to those of the populace who are religious - and there are many - the idea of a universal foundation may be quite agreeable. It is in the nature of religion, especially the monotheistic religions, to establish doctrines claiming universal truth and universal obligation. This does not obviously fit well with the foundational pluralism Vincent espouses. When Vincent sides with the postmoderns in embracing diverse bases for politics, he puts himself at odds with Locke; however, his belief that a foundation is essential is something that he shares with Locke. What, though, is Locke's foundation? The purpose of this article is to provide an answer to this fundamental question.

\section{\$2. Locke's foundation for politics}

Locke's 'law of nature' provides that foundation. It is both a moral foundation and a theological one. What I mean is that the principles that constitute the foundation of political society and government are moral inasmuch as the body of these principles, the 'law of nature', includes duties to ourselves and to others. At the same time their source is theological inasmuch as that law proceeds from God, and contains duties to Him, including, properly speaking, all those duties to ourselves and others that supply its moral content. The 'law of nature' is known by reason and legislated by God. Christians may go further and accept the biblical support of the

\footnotetext{
${ }^{4}$ As by Jeremy Waldron, God, Locke, and Equality: Christian Foundations in Locke's Political Thought (Cambridge, 2002)
} 
Adamic, Mosaic and New Covenants, all of which is consistent with, complements, and in some respects supplements what is known by reason and as such may be assimilated, in ordinary speech, to 'the law of nature'. For the purposes of politics, however, Locke does not require this further scriptural validation by divine positive law. Since the 'law of nature' is reason, its moral content can be known universally and, so to speak, ordinarily: it is an inference, or inferences, from sense data and reflection, not something received by extraordinary inspiration. That nonChristians who, almost by definition, do not assent to the biblical covenants by which people make themselves members of the body of Christ, do not assent to them is in this respect beside the point. The 'law of nature' that governs political society and government is accessible to human reason - something universal. Nevertheless, the 'law of nature' does not stand alone because, as Locke states throughout his writings, this law is enacted by a superior will; and thus, to have a binding effect, God as its legislator must be known and acknowledged. This does not present a problem, because, according to Locke, natural reason can clearly understand the moral content of the law of nature and see that God is its legislator.

In either case, Locke's idea of the 'law of nature' is theological -whether directly related to his covenant theology as expressed in Scripture, or known through 'reason' alone. In the latter case it is theological because the existence of God as its legislator is a rationally irresistible and unassailable conclusion. To Locke's mind, all human knowledge culminates in Him. This point was made emphatically in his late work, Of the Conduct of the Understanding:

There is...one Science...incomparably above all the rest...Theology, which containing the Knowledge of God and his Creatures, our Duty to him and our fellow Creatures, and a view of our present and future State, is the Comprehension of all other Knowledge directed to its true end, i.e., the Honour and Veneration of the Creator, and the Happiness of Mankind...the Works of Nature, and the Words of Revelation, display it to Mankind in 
Characters so large and visible, that those who are not quite blind may in them read, and see the first Principles and most necessary Parts of it. ${ }^{5}$

And it is presupposed in and by the argument of the Second Treatise, which uses reason and revelation in concert to establish its central claims, This does not mean that Locke is advocating a Christian commonwealth (I will return to this point shortly); yet the fundamental organizing concept of this work-the law of nature-requires theism and is confirmed in the words of revelation. Whatever one's view of Christianity, pro or contra, atheism is not a rationally eligible posture to adopt.

Thus, in my view, the Second Treatise presents two options: a commonwealth of Christians, who believe the law of nature is known through the Adamic, Mosaic and New Covenants of Scripture; or a theistic commonwealth of Christians and nonChristians, for whom the law of nature is known through reason and divinely promulgated. 'A commonwealth of Christians' and 'a theistic commonwealth' are phrases Locke does not employ. To avoid confusion, I do not use the term 'Christian commonwealth', because Locke clearly states in his Letter concerning Toleration that 'There is absolutely no such thing, under the Gospel, as a Christian commonwealth'. 6 This is the case because Locke considers 'toleration to be the chief characteristical mark of the true Church', 7 and while he believes Christianity to be the true religion, he insists that religion cannot be imposed upon an individual, there being no agency on earth authorized to induce religious belief by

${ }^{5}$ John Locke, Of the Conduct of the Understanding (Bristol, 1996), 66.

${ }^{6}$ John Locke, A Letter concering Toleration (trans. by William Popple), printed in John Locke: Political Writings, ed. David Wootton (Indianapolis, IN, 2003), 418. In Ecclesia (1682), a brief note on Hooker's description of a church as a supernatural, voluntary society, Locke says this about the church: 'being a supernatural societie, \& a societie by consent The secular power which is purely natural nor any other power can compel one to be of any particular church societie there being many such to be found', thus ruling out a national church, coextensive with the state, in which membership of the church is required and compelled by the civil authorities. See John Locke, Ecclesia (1682) in John Locke: Writings on Religion, ed. Victor Nuovo (Oxford, 2002), 80.

\footnotetext{
${ }^{7}$ Locke, Letter concerning Toleration, 390.
} 
force, and it being in the nature of the understanding 'that it cannot be compelled to the belief of anything by outward force. ${ }^{8}$ Although Locke believes it is reasonable to insist on theism and not Christianity, he ultimately desires a commonwealth of Christians. ${ }^{9}$

Of course it is possible to argue that political theory only needs a moral foundation understood by reason alone, without any divine authority, along the lines of Immanuel Kant's Religion within the Limits of Reason Alone (1793), but that is not what Locke argued.

\section{§3. Locke's Political Theology}

Before entering the specifics of my analysis, I need to address my general claim that the Second Treatise is an exercise in political theology. Political theology is an ambiguous term and it is as well to clarify it. By the term political theology I mean claims about God in the form of statements on the status, legitimation, aim and structure of political order, including the relation of this order to religion, through which the meaning of the political order and its place in the divine economy are elicited. The same term can also be used more narrowly to refer to an interpretation of Christian revelation which assumes the necessary involvement of Christianity, Christians and the Church in sustaining or changing the socio-political order to the purpose of realising the ends of Christian existence. ${ }^{10}$ The scholarly literature on Locke in the last two generations has not always distinguished these two senses of

${ }^{8}$ Ibid., 395.

${ }^{9}$ Compare Teresa M. Bejan, 'Evangelical Toleration', The Journal of Politics 77 (2015): 1103-1114.

${ }^{10}$ These two senses of the term are close to what Ernst-Wolfgang Böckenförde has called respectively 'institutional' and 'appellative' political theology, though I differ from him in taking the first sense of the term to embody an appeal to human reason rather than faith. See his 'Politische Theorie und politische Theologie: Bemerkungen zu ihrem gegenseitigen Verhältnis', in Religionstheorie und Politische Theologie, ed. Jacob Taubes. Vol. 1. Der Fürst dieser Welt. Carl Schmitt und die Folgen (Munich, 1983): 1625. I do not consider here the third, juridical, sense of the term he distinguishes, associated with the German jurist Carl Schmitt, which treats the central concepts of state and legal theory as secularized theological concepts. 
the term very clearly, with the result that questions about the place of God in Locke's thought have frequently been run together with questions about his own Christian beliefs, or lack thereof, and their relevance to his political thinking.

Locke scholarship in the last twenty years or so has largely discredited Leo Strauss' view that Locke's Christian belief was a cover for a closet atheism, or, as Michael Zuckert states, that Locke reinterprets Christianity 'so as to use it to overcome the attitudes characteristic of the biblical orientation', as John Dunn's assertion that Locke's arguments 'rest on a series of theological commitments' ${ }^{11}$ has been taken up by a new generation of scholars who have sought to explore further the roles played by God in Locke's thought. Many scholars have followed Dunn's lead of reading, studying and interpreting Locke's religious writings and seeing how integral they are to all of his thought. The best work on Locke's theology is that of Victor Nuovo. ${ }^{12}$ However, Nuovo's superb scholarship on Locke's religious thinking is broad and does not address the main subject of this article-covenant theology and the Second Treatise.

Despite this shift in recent scholarship, interpretions of Locke's work as political theology have been relatively few; ${ }^{13}$ however,

${ }^{11}$ John Dunn, The Political Thought of John Locke (Cambridge, 1969), xi.

${ }^{12}$ Nuovo has published, with an introduction, an unabridged edition of Locke's The Reasonableness of Christianity as Delivered in the Scriptures (Bristol, 1997); an edited volume of heretofore unpublished religious writings, John Locke, Writings on Religion (Oxford, 2002); an edited volume, John Locke and Christianity, Contemporary Responses to The Reasonableness of Christianity (Bristol, 1997); Christianity, Antiquity, and Enlightenment: Interpretations of Locke (Dordrecht, 2011); and his most recent text, an edited volume, John Locke: Vindications of The Reasonableness of Christianity, and Other Theological Writings (Oxford, 2012). I look forward to Nuovo's article, 'Locke's Hermeneutics of Existence and his Representation of Christianity', forthcoming in Luisa Simonutti (ed.), Conscience and Scripture. Locke and Biblical Hermeneutics (Dordrecht, in preparation).

${ }^{13}$ Nuovo did not use the term 'political theology' in these works, but the following assessment in his chapter on Locke's religious thinking and politics means the same thing: 'My conclusion from the foregoing interpretation is that Locke was fundamentally a Christian thinker, motivated by Christian religious concerns, and that this applies not only to his philosophical thought, but to his theology and political philosophy'. Nuovo, Christianity, Antiquity, and Enlightenment: Interpretations of Locke, 245. 
Jeremy Waldron in his book, God, Locke, and Equality: Christian Foundations of John Locke's Political Thought (2002) presents Locke as a Christian thinker, as does Kim Ian Parker in his book, The Biblical Politics of John Locke (2004). ${ }^{14}$ In both monographs, Locke's covenant theology is not considered. Greg Forster's claim in his book, John Locke's Politics of Moral Consensus (2005) is that Locke's Two Treatises sought to deal with the dispute over 'what moral theory should be the basis of, and therefore constrain, government action'. ${ }^{15}$ According to Forster, the moral consensus Locke was articulating was one that would appeal to all faith traditions, a civil theology that could accommodate any theistic religion. Forster's view coincides with the second interpretative option I present-the theistic commonwealth. Nevertheless, Forster's characterization of Locke's thought as moral and only instrumentally religious cannot be called political theology, and in this way it is different from mine.

Finally, in her recently published book, Religion in Public: Locke's Political Theology (2014), Elizabeth A. Pritchard states that 'Locke's project is more accurately termed a political theology rather than a civil religion'. ${ }^{16}$ I quite agree. Pritchard's book is not about Locke's covenant theology, but is rather an application of Locke's thinking to contemporary debates about the privatization of religion and relations between body and sign, and coercive or punitive power versus persuasive power, the latter emphasizing

${ }^{14}$ Waldron, God, Locke, and Equality; Kim Ian Parker's book The Biblical Politics of John Locke (Ontario, 2004), and John Marshall's book John Locke: Resistance, Religion and Responsibility (Cambridge, 1994) - the latter a comprehensive historical analysis of Locke's theological, moral, and political thought-are all excellent contributions to the study of the relationship between Locke's religious and political thought. It should be noted that Waldron's book makes extensive use of arguments first developed in Ian Harris, The Mind of John Locke (Cambridge, 1994), in which the difference between Locke's natural theology and his treatment of Christianity is marked more carefully and consistently.

${ }^{15}$ Greg Forster, John Locke's Politics of Moral Consensus (Cambridge, 2005), 17.

${ }^{16}$ Elizabeth A. Pritchard, Religion in Public: Locke's Political Theology (Stanford, CA, 2014), 10. 
'opinion, argument, persuasion, and fashion' ${ }^{17}$ It is an interesting analysis, one that, according to Pritchard, is a reconstruction of Locke's writings, and not his 'real intentions' ${ }^{18}$ I commend any work that takes Locke's theology as central to his thinking. My approach differs in that I am attempting to provide a coherent account of Locke's intentions, not an application of his thinking.

In light of the increased volume of scholarly writing about the fundamental importance of Locke's religious thinking, I may not seem to be breaking new ground in claiming that the Second Treatise is a piece of political theology. However, distinguishing the different senses of political theology as I have done enables me to avoid some of the confusions of thought and expression that have led scholars to speak somewhat misleadingly of 'Christian foundations in Locke's political thought', and to explain how those confusions have arisen. ${ }^{19}$ For Locke, the law of nature is identical in content to the biblical covenants, but it does not replace, nor is it replaced by them. That Locke's central arguments relied upon a natural theological foundation does not mean that they opposed Christianity, still less that he used Christian language to disguise anti-biblical or atheistic sentiments. Rather he used it to develop his own account of Christianity as delivered in the Scriptures.

Locke's covenant theology is the framework of The Reasonableness of Christianity, As Delivered in the Scriptures (1695) and found throughout A Paraphrase and Notes on the Epistles of St Paul (posthumous, 1705-07). ${ }^{20}$ In this article, The

${ }^{17}$ Ibid., 3.

${ }^{18}$ Ibid., 9.

${ }^{19}$ See the full title of Waldron, God, Locke, and Equality. At the same time the article challenges John Dunn's claim (in Locke (Oxford, 1984), ch. 3) that Locke's failure to demonstrate the theistic foundation of the political morality that he took for granted in the Second Treatise prompted a retreat into fideism that was tacitly confessed in the argument for the necessity of revelation made in The Reasonableness of Christianity. I argue that reason and revelation were mutually reinforcing in Locke's political theology from the beginning and that no such retreat occurred.

${ }^{20}$ A Paraphrase and Notes on the Epistles of St Paul to the Galatians, 1 and 2 Corinthians, Romans, Ephesians ed. Arthur W. Wainwright (2 vols., Oxford, 1987). 
Reasonableness of Christianity is the primary source on which I rely when construing the desideratum of the Second Treatise as a commonwealth of Christians. For the analysis of Locke's theistic commonwealth, his earlier Essays on the Law of Nature (16631664) are more significant.

To begin, a brief look first at Locke's religious beliefs will provide a context for his covenant theology.

\section{§4. Locke's Christianity}

What Christianity means for Locke is a complicated question and one I sought to address in previous work by examining the theological debates he was embroiled in during the 1690s. ${ }^{21}$ What I discovered is that Locke was an unorthodox Christian. Because of his view of the Trinity, and other theological doctrines, such as original sin, Christ's atonement, and mortalism, ${ }^{22}$ Locke was challenged by Calvinist Anglicans, such as John Edwards (16371716). Yet there is no doubt that Locke was a Christian: he believed that Jesus was the Messiah, that Scripture was God's Holy Writ, and that Christianity was the true religion. As Victor Nuovo writes, 'That Locke was a Christian, and a very serious one besides, is no longer a matter of controversy'. ${ }^{23}$ In A Second Vindication of the Reasonableness of Christianity (1697), Locke says this about himself:

A Christian I am sure I am, because I believe Jesus to be the Messiah, the King and Saviour promised, and sent by God: And as a Subject of his Kingdom, I take the rule of my Faith, and Life, from his Will declar'd and left upon Record in the inspired Writings of the Apostles and Evangelists in the New Testament: Which I endeavor to the most of my power, as is my Duty, to understand in their true sense and meaning. To lead me into their true meaning, I know no infallible Guide, but the same Holy Spirit, from

${ }^{21}$ See my dissertation, 'The Theological Context of John Locke's Political Thought' (Ph.D. diss., The Catholic University, 2006).

${ }^{22}$ Wainwright, 'Introduction' to Paraphrase, i. 54.

${ }^{23}$ Nuovo, Christianity, Antiquity, and Enlightenment. Interpretations of Locke, xvi. 
whom these Writings first came. ${ }^{24}$

This is as clear a summary of Locke's Christian commitments as one could wish. This article explores these commitments at greater length; and his own writings bespeak them at greater length still. No doubt more could be said about what is omitted from, or hedged about in, this summary - neither the Trinity nor the Incarnation is mentioned as an article of faith, and Locke's published writings were non-commital about both. Even so, certain things can be said with some confidence about his Christian views. Locke was a Protestant Anglican, anti-Calvinist, Latitudinarian, and not Socinian. ${ }^{25}$ I also have examined whether or not Locke was Socinian, and determined that he was not. ${ }^{26}$ For the purposes of this article, I will focus on Locke's covenant theology, which was not antagonistic to the Anglican High Churchmen, but on specific points was the cause of heated debate-namely Locke's denial of original sin in the Reasonableness, and the proposition that believing Jesus is the Messiah meets the faith requirement of the New Covenant.

${ }^{24}$ John Locke, A Second Vindication of the Reasonableness of Christianity (London: A. and J. Churchill, 1697), 344-45.

${ }^{25}$ Locke's anti-Calvinism is addressed in this article. Latitudinarian was a label given to those in seventeenth-century England who believed in ecclesiological pluralism, or 'latitude', and in a distinction between fundamental and non-fundamental articles of faith in order to resolve fractures within the Anglican Church. Socinianism refers to a heretical creed arising in Poland in the mid-seventeenth century that made its way into Western Europe. Socinianism refers to a heretical creed arising in Poland in the mid-seventeenth century that made its way into Western Europe.

${ }^{26}$ While some of Locke's views are similar to Socinianism, such as reliance on Scripture and reason, and denial of original sin, I do not believe he was Socinian. The major attack on Locke was his connection to the Socinian denial of the Trinity, an issue on which Locke never gave a definitive pronouncement. See my dissertation, passim, for an analysis of Locke's religious views. It seems that the fashion for depicting Locke as a Socinian has in any case waned since Marshall's various assertions and retractions. Compare Marshall, John Locke, 144, 345, 425n; idem, 'Locke, Socinianism, "Socinianism", and Unitarianism', in English Philosophy in the Age of Locke, ed. M. A. Stewart (Oxford, 2000), ch.5 and Nuovo's observations on the matter in Writings on Religion, (li-lii). 


\section{§5. The Law of Works: Adamic and Mosaic Covenants}

In the Reasonableness of Christianity (1695), Locke articulates a theology associated with Covenant Anglicanism that itself can be traced to the 'federal' theology of the late sixteenth century. ${ }^{27}$ To counter the doctrine of justification by faith alone and the Calvinist doctrines of predestination and election, Zwingli, Bullinger, and the Rhineland theologians developed a 'federal' covenant theology with terms of conditionality and bilateralism. In contrast to Calvin and the Genevan theologians' unilateral, unconditional covenantalism, Zwingli and Bullinger believed that God's covenant with man was bilateral, conditional on man's response, and fulfilled by the obedience of the individual.

The Anglican Henry Hammond (1605-60), cited by Locke at the beginning of the Reasonableness, adopted the Arminian view in his Practical Catechism (1645). Jacob Arminius (1559-1609) presented a theology locating the primary covenant between God and Adam at creation, rather than with Mosaic law. This view is expressed in the Westminster Confession of Faith (1647), a Puritan and Calvinist doctrinal statement in most ways, except for locating the primary covenants in Adam and Moses and referring to both as the covenant of works; ${ }^{28}$ what Locke calls 'The Law of Works'. As Locke writes: 'Tis plain, that under the Law of Works is comprehended also the Law of Nature, knowable by Reason, as well as the Law given by Moses. ${ }^{29}$

In Hammond and other earlier covenant theologians, there was a shift from Moses back to Adam, so that the covenant of works

${ }^{27}$ For further analysis, see Joanne Tetlow, 'John Locke's Covenant Theology', Locke Studies, 9 (2009): 167-99.

28 The first covenant made with man was a covenant of works, wherein life was promised to Adam, and in him to his posterity, upon condition of perfect and personal obedience. The covenant or law of works is related to Adam's transgression of God's command in Eden, and the law delivered to Moses at Mount Sinai. The Westminster Confession of Faith, ed. G. I. Williamson (Philadelphia: Presbyterian and Reformed Publishing Company, 1964), 63.

${ }^{29}$ John Locke, The Reasonableness of Christianity, As Delivered in the Scriptures, ed. John C. Higgins-Biddle (Oxford, 1999), 18. 
could apply universally, not exclusively to the Jews. Because of this move and a rejection of focusing on the Abrahamic Covenant of faith, Covenantal Anglicanism 'was a religion of moral duty'. 30 Hammond, as Locke does, stresses that Christians must live a life of faith, repentance, and sincere effort to keep the divine law. The fundamental requirement of the Law of Works is perfect obedience, and this applies universally to all mankind. Locke explains:

The Law of Works, then, in short, is that Law, which requires perfect Obedience, without any remission or abatement; So that by that Law a man cannot be Just, or justified without an exact performance of every tittle. Such

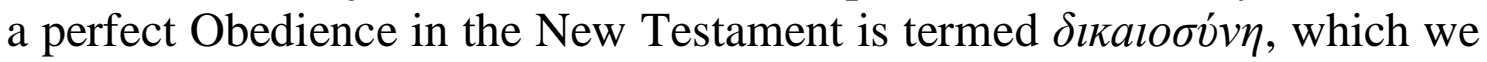
translate Righteousness. ${ }^{31}$

The law of nature given by God at creation to Adam, who is the archetype and progenitor of the human species, is moral and universal. Thus, it is Adam, not Moses, who is the central biblical figure in Two Treatises of Government. Locke's biblical denunciation of Filmer's 'divine right' theory of a hereditary claim to political power through Adam is based on a belief that Adam's representative role, such as it is, is not related to ruling authority, but to individual consent and action related to a covenant with God. Each individual has a moral and theological association with the Adamic covenant (law of nature), and this includes the choice to sin. Because of Locke's disdain for the deterministic outcome of the doctrine of original sin in Adam, he adopts an unorthodox interpretation of the Fall.

\section{\$6. Adamic Covenant and Original Sin}

Locke rejects Samuel von Pufendorf's 'federal' covenant theology where Adam as a federal head represents mankind vis-à-vis

${ }^{30}$ Neil Lettinga, 'Covenant Theology Turned Upside Down: Henry Hammond and Caroline Anglican Moralism: 1643-1660,' Sixteenth Century Journal 24 (1993), 659. For Hammond in relation to his contemporaries, see Sarah Mortimer, Reason and Religion in the English Revolution: the Challenge of Socinianism (Cambridge, 2010).

${ }^{31}$ Locke, Reasonableness, 17. 
original sin. For Locke, Adam's representation of mankind is narrow; it is only Adam's death that his posterity inherits. Original sin does not flow from Adam's transgression in the Garden of Eden; otherwise there would be no individual moral responsibility. Locke rhetorically comments: 'But as I remember every one's sin is charged upon himself only'. ${ }^{32}$

Adam's transgression of the Law of Nature was met with God's penalty of death. ${ }^{33}$ Thus, all human beings who break the law of nature die; that is why death reigned from Adam until Moses without a divine positive law. Since the law of nature is the Adamic covenant, all subsequent individuals who violate it incur its penalty - death. The only way to escape death is perfect obedience to the law of nature. But, why would God require perfect obedience to a law that no individual can meet? Locke answers:

It was such a Law as the Purity of God's Nature required, and must be the Law of such a Creature as Man, unless God who would have made him a Rational Creature, and not required him to have lived by the Law of Reason, but would have countenanced in him Irregularity and Disobedience to that Light which he had; and that Rule, which was suitable to his Nature: Which would have been, to have authorized Disorder, Confusion, and Wickedness in his Creatures. For that this Law was the Law of Reason, or as it is called of Nature, was shall see by and by: ${ }^{34}$ And if Rational Creatures will not live up to the Rule of their Reason, who shall excuse them? ${ }^{35}$

Since God created man as a rational creature, the law of reason must be the rule for righteousness or justice; for God to require any less would be 'unreasonable'. Similarly, it would be unreasonable

${ }^{32}$ Ibid., 9.

${ }^{33}$ Ibid., 6.

${ }^{34}$ See ibid.,18-19, and cf. 119. Also Essays on the Law of Nature, 199, on the harmony between rational nature and natural law. In Two Treatises, II. 13, Locke admitted that 'Confusion and Disorder' might arise in the state of nature under the law of nature alone, but he did not, of course, suggest that God 'authorized' such consequences. His references to 'Rebellion', 'Government and Order', and 'Lawless Exorbitancy' in the lines below indicate the political orientation of his thought (Higgins-Biddle's note).

${ }^{35}$ Ibid., 13-14. 
of God to hold man responsible for the sin of another by an Adamic representation never chosen. Individual consent is crucial. ${ }^{36}$ Adam in his own right violated a divine positive command that was issued strictly to him. No individual received that particular divine command other than Adam, and thus only Adam is responsible for own his transgression.

Locke's unorthodox interpretation of sin supports his belief that man enters into a bilateral, conditional covenant with God based on consent. From this proposition, Locke argues in the Second Treatise that Adam is not the origin of political power, but the law of nature given to him is.

\section{\$7. Mosaic Covenant and the Moral Law}

The Mosaic Covenant is part of the law of nature, because it consists of divine positive commands. It is distinguished from the Adamic Covenant, because it is written rather than unwritten, and by its peculiar application to the Jews. According to Locke, the parts of the law of Moses which are superseded by the Law of Faith are concerned with 'the outward Worship, or Political Constitution of the Jews, and [are] called the Ceremonial and Judaical Law' ${ }^{37}$ The moral part of the Mosaic Covenant, such as the Ten Commandments, because it conforms to the 'Eternal Law of Right, is of Eternal Obligation', ${ }^{38}$ is not abrogated by the Law of Faith. As part of the law of nature, the moral law of the Mosaic Covenant is part of the Law of Works and the Law of Faith; both are universal and require faith and obedience. The Mosaic Covenant is not explicitly mentioned in the Second Treatise, but Locke refers to

\footnotetext{
${ }^{36}$ Without consent, there is no liability. This would suggest that Adam could not pass anything onto his posterity without their consent, so how does Locke account for Adam's transmission of death to all mankind? He anticipates this question. Locke queries: 'How doth it consist with the Justice and Goodness of God, that the Posterity of Adam should suffer for his sin; the Innocent be punished for the Guilty?' Locke's answer is that individuals are punished for their own sins, not Adam's, and a temporary mortal life is better than no life at all, which would not be the case if death resulted in eternal torment, a belief of Calvinists and others. Reasonableness, 9-10.

${ }^{37}$ Ibid., 19.

${ }^{38}$ Ibid.
} 
Exodus, Leviticus, Judges and other Old Testament passages, the moral aspects of which have universal application.

For Locke, justification or salvation is two-fold: faith or belief in God's promises and requirements for righteousness made in the Abrahamic Covenant of the Old Testament, ${ }^{39}$ or the Covenant of Grace in the New Testament; and obedience to the laws of God's kingdom, i.e., the law of nature.

\section{\$8. The Law of Faith: New Covenant of Grace}

As I stated, the Law of Faith, or New Covenant of Grace, contains all the moral law of nature under the Law of Works, and both have the same conditions: 'faith' and 'obedience'. What is 'new' and different about the Law of Faith is that imperfect obedience is forgiven in and by belief in Christ. The New Covenant of Grace enacted by Christ, the second Adam, restores immortality, as 'faith is allowed to supply the defect of full Obedience; and so the Believers are admitted to Life and Immortality as if they were Righteous'. ${ }^{40}$ Still, faith is not enough. Locke writes: 'That Christ does require Obedience, sincere Obedience, is evident from the Laws he himself delivers... and from the Sentence he will pass when he comes to Judge' ${ }^{41}$ And:

This Righteousness therefore, a compleat Obedience and freedom from Sin, are still sincerely to be endeavoured after. And tis not where promised, That those who persist in a willful Disobedience to his Laws, shall be received into the eternal bliss of his Kingdom, how much soever they believe in $\operatorname{him}^{42}$

Consistent with his 'federal' theology of a bilateral, conditional

\footnotetext{
${ }^{39}$ Locke discusses the Abrahamic Covenant in the Paraphrase. The faith requirement of the Old Testament Abrahamic Covenant is the same as that of the New Covenant of Grace.

${ }^{40}$ Ibid., 9.

${ }^{41}$ Ibid., 120.

${ }^{42}$ Ibid., 130.
} 
covenant, sincere obedience, or repentance, is required. In the Reasonableness, Locke cites numerous passages about repentance from the Gospels and the Book of Acts to support this proposition.

Furthermore, Jesus in the Gospels added to the law of nature in the Law of Works. Here Locke emphasizes Jesus as King and Legislator, who has the right to expand the content of the law of nature as part of the laws of his Kingdom.

\section{§9. New Testament Morality}

What Christ did for the law of nature is an innovative and pivtoal point of the Reasonableness. Aristotle and the ancient philosophers had done much in explicating moral good and evil, but there was no divine authorization to give their ethical and moral principles traction throughout the universe. This perennial problem that philosophy could not solve was remedied by Christ's authoritative proclamation of the law of nature as the foundation for morality. Locke observes that "Tis too hard a task for unassisted Reason, to establish Morality in all its parts upon its true foundations, with a clear and convincing light'. ${ }^{43}$ A comprehensive claim over the lives of all mankind as to the duties of morality was needed. Locke says:

But such a Body of Ethicks, proved to be the Law of Nature, from principles of Reason, and reaching all the Duties of Life; I think no body will say the World had before our Saviour's time. 'Tis not enough, that there were up and down scattered sayings of wise Men, conformable to right Reason. The Law of Nature, was the Law of Convenience too... But these incoherent apophthegms of Philosophers, and wise Men; however excellent in themselves, and well intended by them; could never make a Morality, whereof the World could be convinced, could never rise up to the force of a Law that Mankind could with certainty depend on. ${ }^{44}$

Referring to mankind, Locke says: 'They were under no Obligation: The Opinion of this or that Philosopher, was of no

\footnotetext{
${ }^{43}$ Locke, Reasonableness, 148.

${ }^{44}$ Ibid., 151-52.
} 
Authority ${ }^{45}$ Christianity provides the complete morality, because it provides the complete moral authority: God Himself as Lawgiver. Even assuming arguendo that it is possible one could gather all the moral rules 'from Solon and Bias in Greece; Others from Tully in Italy: And to compleat the Work, let Confutius, as far as China, be consulted; And Anacarsis the Scythian contribute his share. What will all this do, to give the World a compleat morality, that may be to Mankind, the unquestionable Rule of Life and Manners?'46

Thus two fundamental problems with natural religion are presented: lack of divine authorization, and lack of a complete and whole morality for mankind. New Testament morality is precisely what philosophers had been searching for. Locke writes that:

Such a Law of Morality, Jesus Christ hath given us in the New Testament; But by the latter of these ways, by Revelation. We have from him a full and sufficient Rule for our direction; And conformable to that of Reason. But the truth and obligation of its Precepts have their force, and are put past doubt to us, by the evidence of his Mission. He was sent by God: His Miracles shew it; And the Authority of God in his Precepts cannot be questioned. Here Morality has a sure Standard, that Revelation vouches, and Reason cannot gainsay, nor question; but both together witness to come from God the great Law-maker. $^{47}$

This New Testament morality contains the divine commands of Christ to his Subjects, and the 'Objects of Faith' 48 written in St Paul's Epistles; the latter are part of the believer's whole duty to God, but do not contain fundamental articles of faith for justification or salvation. The distinction Locke makes between the Gospels and St Paul's Epistles about fundamental articles of faith was a major issue in his clash with Calvinist John Edwards.

\footnotetext{
${ }^{45}$ Ibid., 151.

${ }^{46}$ Ibid., 150.

${ }^{47}$ Ibid., 153.

${ }^{48}$ Ibid., 168.
} 
Thus although the faith for justification is satisfied by belief in Jesus as the Messiah, the obedience required encompasses the mandates of Christ and those of St Paul. For the Christian, the law of nature is substantial.

\section{\$10. Locke's Second Treatise}

As I have proposed, this law of nature provides the moral foundation for society and civil government. In the following sections, I provide evidence of Locke's law of nature in the Second Treatise and its connection with the Adamic Covenant. Some of this evidence is direct, some is implicit. Still, I believe the nexus is there, and that the central concepts of Locke's covenant theology, though not published until later in the Reasonableness, existed at the time of the Second Treatise. Victor Nuovo comments that Locke was reading into the Reasonableness the position he had taken in the Second Treatise, that Adam was not the origin of political power nor the archetypal possessor of a divine right to rule. Nuovo also agrees that it is the same law of nature in the Reasonableness and Second Treatise, while acknowledging its different applications. ${ }^{49}$

On my account, the law of nature in the Second Treatise under one interpretation creates a commonwealth of Christians, who believe this law has the same moral meaning as the covenants in Scripture. Let me say a little more about the interpretation I have in mind and the evidence that supports it.

\section{\$11. A Commonwealth of Christians}

Given the significance of the biblical Adam in Two Treatises of Government, the connection between the law of nature and the Adamic Covenant is clear. While there is some direct evidence of the Mosaic Covenant, both it and the New Covenant require the assumption stated above, that the law of nature in the Reasonableness is the same as that in the Second Treatise. Nuovo's

49 Nuovo, Christianity, Antiquity, and Enlightenment, 91, 244. 
support for this assumption rests on the fact that 'Locke's interest in sacred history did not begin in $1694{ }^{\prime 50}$, when he started taking notes on a range of theological subjects in his commonplace book entitled Adversaria Theologica 94 in preparation for writing the Reasonableness. ${ }^{51}$ It was already evident in the pages of Two Treatises.

\section{\$12. Adamic Covenant as the Law of Nature}

After refuting Filmer's claims about the divine right of kings to rule in the manner of Adam in the First Treatise, Locke begins the Second Treatise by summarizing his argument. According to Locke, 'there being no law of nature nor positive law of God that determines which is the right heir in all cases that may arise, the right of succession, and consequently of bearing rule, could not have been certainly determined'. ${ }^{52}$ The two bases of authority-the law of nature and positive law of God (Scripture) - do not support Filmer's argument that the origin of political power is in Adam by private dominion or paternal jurisdiction. Consequently, Locke sets out to provide another origin of political power in the Second Treatise from these same two bases of authority.

References to Adam are more explicit in Locke's chapters on 'property' and 'paternal power', because Filmer's theory of Adamic hereditary rule relies, as I have said, on 'private dominion' and 'paternal jurisdiction'. In rebutting Filmer's claims, Locke interprets Adam in connection with the law of nature, not political rule. But Adam and the law of nature, or the Adamic Covenant, are also significant in the early chapters where Locke explains the state of nature.

${ }^{50}$ Ibid., 37. See also idem, John Locke: The Philosopher as Christian Virtuoso (Oxford, 2017), 246.

51 Nuovo, Christianity, Antiquity, and Enlightenment, 23-24. As early as 1678, citations from biblical authors, dates of the sacred calendar in historical Old Testament books, and other notations were made in his interleaved bibles. Also, Locke wrote up part of Nicolas Toinard's Harmony of the Gospels in a notebook about the chronology of the life of Jesus. Ibid., 37.

${ }^{52}$ Locke, Two Treatises, II. 3, 267. 


\section{\$13. The State of Nature}

Locke writes that 'To understand Political Power right, and derive it from its Original, we must consider what State all Men are naturally in, and that is, a State of perfect Freedom to order their Actions, and dispose of their Possessions, and Persons as they think fit, within the bounds of the Law of Nature'. ${ }^{53}$ It is a condition of perfect freedom, because mankind consists of creatures of one species with the same nature. What is the law of nature that binds this state of nature?

Reason, which is that Law, teaches all Mankind, who will but consult it, that being all equal and independent, no one ought to harm another in his Life, Health, Liberty, or Possessions. For Men being all the Workmanship of one Omnipotent, and infinitely wise Maker; All the Servants of one Sovereign Master, sent into the World by his order and about his business; they are his Property, whose Workmanship they are, made to last during his, not one another's Pleasure. ${ }^{54}$

Both the law of nature and divine positive law, or Scripture, are intertwined in this text. Locke has said that man is by nature perfectly free, and in a state of equality as to that freedom, because as he explains, the individual is God's property. All of mankind is the workmanship of God, or God's property; and thus the law of nature, or reason, that God has given, binds individuals naturally to their Creator. This is consistent with Ephesians 2:10, the biblical text Locke paraphrases in equating 'workmanship' with 'property' ${ }^{55}$ God as the one omnipotent and infinitely wise Maker created mankind, who are God's workmanship, or work of art, or property. Reason teaches these truths about the law of nature to all mankind. Though the Adamic Covenant is not specifically referred to, it is implied inasmuch as God gave the law of nature to Adam at creation, a position elaborated by Locke in the Reasonableness.

${ }^{53}$ Ibid., II. 4, 269.

${ }^{54}$ Ibid., II. 6, 271.

55 'For we are his workmanship, created in Christ Jesus unto good works, which God hath before ordained that we should walk in them'. 
Further, when describing the state of nature where the law of nature rules, Locke refers to Cain and Abel and 'the great Law of Nature, Who so sheddeth Man's Blood, by Man shall his Blood be shed'. ${ }^{56}$ Again, the law of nature and divine positive law are assimilated by Locke in this passage. He characterizes Cain's murder of Abel as a violation of the law of nature, or renouncing the reason that God gave to mankind. Cain's sin is charged against him, an example of how disobedience to the law of nature results in death, the penalty of mortality imposed on Adam and his posterity. The breakdown of moral order in the state of nature that leads to the state of war is the result of "violating the Law, and varying from the right Rule of Reason, whereby a Man so far becomes degenerate, and declares himself to quit the Principles of Human Nature, and to be a noxious Creature'. ${ }^{57}$ In these sections, Locke describes how each individual has the executive power, or right, to punish a violation of the law of nature, and take reparation for damages, both of which relate to the right of self-preservation, and the right and duty to preserve mankind as God's property. Thus when Cain murdered Abel by renouncing 'Reason, the common Rule and Measure God hath given to Mankind', he 'declared War against all Mankind, and therefore may be destroyed as a Lyon or a Tyger' ${ }^{58}$ As Adam's posterity, Cain knew the law of nature and that its violation warranted death. Locke quotes Genesis 4:14, when Cain says, 'Every one that findeth me, shall slay me' to show that the law of nature is written on the hearts of all mankind. ${ }^{59}$

The state of war Locke describes using terms such as 'Wolf or Lyon' for those who break 'the ties of the Common Law of Reason' 60 is analogous to a Fall from the law of nature given to Adam at creation. Although Locke does not use the word 'sin', its

\footnotetext{
${ }^{56}$ Locke, Two Treatises, II. 11, 274.

${ }^{57}$ Ibid., II. 10, 273.

${ }^{58}$ Ibid., II. 11, 274.

${ }^{59}$ Ibid.

${ }^{60}$ Ibid., II. 16, 279.
} 
meaning is clear. Disobedience to the law of nature, or reason, changes an individual's status from a human being to a noxious creature, or beast of prey. Reason, or the law of nature, leads men to leave the state of nature and create a political society with a common superior to authoritatively judge those controversies that lead to a state of war. The moral content of the law of nature, or Adamic Covenant, is unchanged in political society; however, when the legislative power enacts law, it takes on a different positive legal form, one in which authoritative adjudication is matched by the present threat of punishment for violation of the rules it laws down. The rules in view purpose to protect, and to resolve controversies about, property.

\section{\$14. Property}

Locke's use of the term 'property' has a much broader meaning than possessions. As Locke says, the end of political society for people is 'to unite for the mutual Preservation of their Lives, Liberties and Estates, which I call by the general Name, Property'. ${ }^{61}$ Since the individual is God's property, he must be self-preserved and all individuals preserved as a whole. The created order of mankind answers to God's teleonomic requirements. The natural right of self-preservation and preservation of mankind in the state of nature arises from duties to God as owner of individual and communal property. Each rational creature in the state of nature has executive power to enforce the two fundamental laws of nature: 'Every one as he is bound to preserve himself', ${ }^{62}$ and 'as much as he can, to preserve the rest of Mankind'. ${ }^{63}$ This state of perfect equality as to the executive power in the state of nature where there is no subordination or superiority of jurisdiction resembles the Adamic Covenant, i.e. man is rational, free and equally subject to the law of nature. Locke states that it is clear God gave the earth to all mankind in common, and this

\footnotetext{
${ }^{61}$ Ibid., II. 123, 350.

${ }^{62}$ Ibid.

${ }^{63}$ Ibid.
} 
proposition can be understood by reason as the right of their preservation, or by revelation, where God granted the world to Adam and Eve and their posterity. ${ }^{64}$ Here Locke quotes Psalm 115:16. ${ }^{65}$ Again, Locke's use of reason and revelation are interconnected.

Further, Locke explains that the law of nature that gave mankind common property also placed limits on its use. Quoting 1 Timothy 6:17, that 'God has given us all things richly', and calling this scriptural passage 'the Voice of Reason confirmed by Inspiration', ${ }^{66}$ Locke interprets this verse as freely permitting the use of property, but only to the extent of enjoyment. Spoilage or destruction of property are not within the bounds of the law of nature. Moreover, since 'God and his Reason commanded him to subdue the Earth, i.e. improve it for the benefit of Life', 67 it must be used in an industrious and rational way. Once again, Locke is referring to the Adamic Covenant.

\section{\$15. Paternal Power}

When Locke discusses paternal power, he specifically links the Adamic Covenant with the law of nature. Locke states that 'Adam was created a perfect Man, his Body and Mind in full possession of their Strength and Reason, and so was capable from the first Instant of his being to provide for his own Support and Preservation, and govern his Actions according to the Dictates of the Law of Reason which God had implanted in him'. Locke goes on to explain how Adam and Eve, the first parents, were 'by the Law of Nature, under an obligation to preserve, nourish, and educate the Children they had begotten, not as their own Workmanship, but the Workmanship of their own Maker, the Almighty, to whom they were to be accountable for them'. Locke

${ }^{64}$ Ibid., II. 25, 285-86.

65 'The heaven, even the heavens, are the LORD'S: but the earth hath he given to the children of men'.

${ }^{66}$ Locke, Two Treatises, II. 31, 290.

${ }^{67}$ Ibid., II. 32, 291. 
states further in this chapter that 'The Law that was to govern Adam, was the same that was to govern all his Posterity, the Law of Reason'. ${ }^{68}$ This is an explicit connection between Adam and the law of nature. Also, there are examples in this chapter of Locke equating the law of nature, or reason, with the divine positive law, or Scripture. ${ }^{69}$ This is a general theme throughout the Second Treatise-reason and revelation are tied together as mutually supporting elements of a single great design. ${ }^{70}$

\section{\$16. Mosaic Covenant as the Law of Nature}

As I stated, the Mosaic Covenant is not explicitly mentioned in the Second Treatise, but Locke refers to it indirectly by using certain passages to support its moral truths. For example, Locke refers to Exodus 21 when arguing that the Jews were not sold into slavery, because the master held no 'absolute, arbitrary, despotical power', including the power to injure, because of the Mosaic law of 'eye for eye, tooth for tooth'. ${ }^{71}$ Also, Locke uses the story of Jephtha and the Ammonites in Judges 11 on several occasions to assert the moral principle that when there is no judge on earth to decide controversies, 'the appeal lies to God in heaven'. ${ }^{72}$ Deuteronomy 8:5 is invoked for the proposition that parents ought to chastise their children with tenderness and affection. ${ }^{73}$ In arguing that the kings and judges of Israel acted more like captains of war, Locke

${ }^{68}$ Ibid., II. 56-57, 305.

69 See other places where Locke cites reason or revelation as support for the proposition that father and mother have an equal share in paternal power; a child's obligation to parents is based on the law of God and nature; and a parent's duty to nourish and educate children is 'woven into the principles of human nature' by God, followed by a citation from Deuteronomy 8:5. Ibid., II. 52, 303; II. 66, 311; II. 67, 312.

${ }^{70}$ For the 'great design of God' and its role in Two Treatises, see Harris, The Mind of John Locke, 214-48.

${ }^{71}$ Locke, Two Treatises, II. 24, 285.

72 Ibid., II. 21, 282; II. 109, 340; II. 168, 379; II. 176, 386.

${ }^{73}$ Ibid., II. 67, 312. 
refers to Judges and 1 Samuel $8 .{ }^{74}$ Locke's references to the 'law of God' or divine positive law (Scripture) can be interpreted to include the moral principles of the Mosaic Covenant.

Another purpose of the Mosaic Covenant was to establish a theocracy. God ruled directly over the people of Israel. All political power-legislative, executive and judicial—was immediately exercised by Yahweh over the Israelite polity. Locke does refer to God's theocracy over the universe in the Second Treatise, ${ }^{75}$ but political rule is 'indirect', something I will examine below.

One additional point is that an analogy can be made with the founding of the commonwealth of Israel as a political model. When Locke talks about men coming out of the state of nature to form a political compact, he has a covenant relationship in mind. The Mosaic Covenant formed, constituted and directed the Israelites as a people and commonwealth in relation to each other and to God. The Israelites entered into a bilateral, express agreement with God at Sinai - the Ten Commandments formed its foundational principles with further laws, statutes, ordinances and regulations to follow. In the Second Treatise, a political compact is created when an individual 'by actual Agreement, and any express Declaration, gives his Consent to be of any Commonweal' ${ }^{76}$ This is an analogy Locke does not make explicitly in the Second Treatise, perhaps because the Israelites transacted with God through Moses rather than each of them as individuals, but I think it fits in broad terms with his covenant theology, particularly because he does compare Moses and Jesus as both founders of covenants and lawgivers. Referring to Locke's view of Moses and Jesus, Nuovo observes that 'Both are lawgivers and both are bearers of divine revelation directly received. Both enjoin a law that, in its moral part, is identical with the law of nature and hence discoverable by reason' ${ }^{77}$

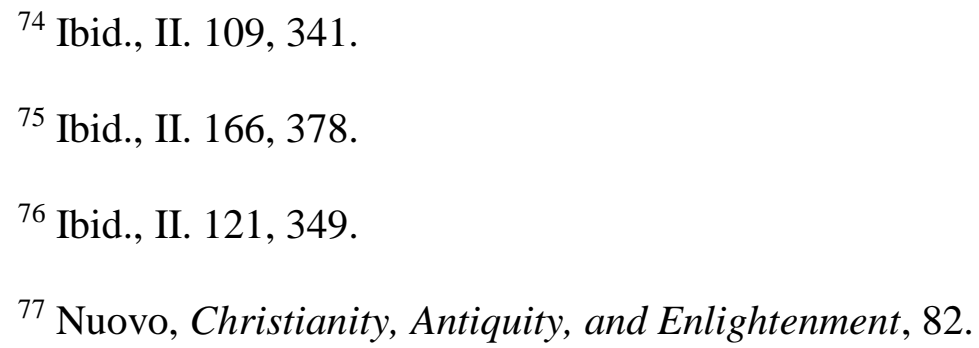




\section{\$17. New Covenant of Grace and Political Power}

In the Second Treatise, the law of nature does not itself indicate or require any particular form of government, i.e. monarchy, aristocracy, or democracy. Rather, it provides the moral ground for the compact of political society, or an independent community, which is Locke's definition of a commonwealth. ${ }^{78}$ When entering into political society by consent, Locke says that men form 'one Body Politick', 'one Community', and 'one Society'. ${ }^{79}$ As Locke states, in political society 'the Majority have a Right to act and conclude the rest', and 'the act of the Majority passes for the act of the whole, and of course determines, as having by the Law of Nature and Reason, the power of the whole' ${ }^{80}$ Locke thinks these political ideas and all others arise from the law of nature, or reason. Stated differently, the Second Treatise is an application of the theological law of nature to political power. The important point here is that Adam was given the law of nature, not political power; the latter Filmer mistakenly asserts when twisting the rope of sand by which he purposes to bind mankind into slavery. In addition, Christ in the New Covenant as the second Adam validates and completes the law of nature without establishing direct political rule.

\section{\$18. Christ's 'Indirect' Political Power}

Christ acts with 'indirect' power in political society and civil government. Locke believed Christ possessed inter alia the attributes of a 'political' sovereign. In the Reasonableness, Locke describes Christ as the King, Ruler, Judge, and Legislator. Adding to the traditional triadic description of Christ as Prophet, Priest and King, ${ }^{81}$ Locke conceives Christ as representing all that is political,

\footnotetext{
${ }^{78}$ Locke, Two Treatises, II. 133, 355.

${ }^{79}$ Ibid., II. 95, 331; II. 97, 332.

${ }^{80}$ Ibid., II. 96, 332.
}

${ }^{81}$ Locke does not disregard the theological importance of Christ as prophet or priest; in fact, one of his two arguments for the divine authenticity of Scripture rests on Christ's 
viz. lawmaking, executing, decreeing, commanding, promulgating, judging and ruling. As Locke states, Christians receive Christ 'for their King and Ruler' and should live 'in a Sincere Obedience to his Law' and 'be his Subjects' and 'live by the Laws of his Kingdom'. Furthermore, all mankind will be judged at the last day by 'the Law of that Kingdom', which is 'that Eternal Law of Right, which is Holy, Just, and Good' and 'of Eternal Obligation'. ${ }^{82}$ All of this is highly political. This is why the phrases 'Law of Works', 'Law of Faith', 'Law of Morality', and 'Laws of his kingdom' are appealing. God and Christ have ultimate political power, and are thus constituted in the various roles of executive, legislative and judicial.

Also, the political roles attributed to Christ in the Reasonableness resemble Locke's definition at the beginning of the Second Treatise:

Political Power then I take to be a Right of making Laws with Penalties of Death, and consequently of all less Penalties, for the Regulating and Preserving of Property, and of employing the force of the Community, in the Execution of such Laws, and in the defence of the Common-wealth from Foreign Injury, and all this only for the Publick Good. ${ }^{83}$

Yet what does it mean to say that Christ has 'indirect' political power in civil society and government in these various capacities? I propose that it means 'indirect' political power through the 'law of nature'. Christ rules a commonwealth of Christians through the 'law of nature'. On this point, I will focus on the legislative aspect

fulfillment of Old Testament prophecy — the other being Christ's miracles — and he refers to Hebrews numerous times in relation to Christ's role as priest. Locke's apparent deemphasis of Christ's priestly role and re-emphasis of Christ's kingly attributes has invited criticism that his Christianity has no Christology. Locke explains that he is simply stating Christ's own self-representation in Scripture as King of the Kingdom of God. Locke refers to Christ as Messiah throughout the Reasonableness to reinforce the fact of his inaugurated Judaic kingship. The Davidic promise was that the Messiah would be a king, prince and ruler who would establish his kingdom.

\footnotetext{
${ }^{82}$ Locke, Two Treatises, II. 11, 117-19.

${ }^{83}$ Ibid., II. 3, 268.
} 
of Christ's indirect power, since Locke believes the legislative is supreme. A claim can be made that Christ's sacred kingship is expressed through proper use of the executive power, which is also bound by the law of nature.

\section{\$19. The Law of Nature and the Legislative}

The predicament of the state of nature was that 'There wants an establish'd, settled, known Law, received and allowed by common consent to be the Standard of Right and Wrong, and the common measure to decide all Controversies between them', ${ }^{84}$ and though the 'law of nature' is in principle clear to all rational creatures, it is not followed, because of bias, interest and ignorance. These established, settled and known laws in political society are to be enacted by the legislature from the law of nature. Locke writes that

The Obligations of the Law of Nature cease not in Society, but only in many Cases are drawn closer, and have by Humane Laws known Penalties annexed to them, to enforce their observation. Thus the Law of Nature stands as an Eternal Rule to all Men, Legislators as well as others. The Rules that they make for other Men's Actions must, as well as their own and other Men's Actions, be conformable to the Law of Nature, i.e. to the Will of God, of which that is a Declaration, and the fundamental Law of Nature being the preservation of Mankind, no Human Sanction can be good, or valid against it. ${ }^{85}$

Locke does not refer to the Adamic Covenant as much in the later chapters of the Second Treatise, but it is implicit that the law of nature has the same meaning throughout this work. Notice again the dual character of the 'law of nature' related to reason, or the source of civil laws for political society, and it being the 'eternal rule to all men' and 'the Will of God'.

Locke explains that known, standing civil or human laws are required, because the law of nature is unwritten, and he quotes Hooker's Ecclesiastical Polity (1593) in a footnote to support the point that the divine law of nature is the source of civil laws:

\footnotetext{
${ }^{84}$ Ibid., II. 124, 351.

${ }^{85}$ Ibid., II. 135, 357-58.
} 
Humane Laws are measures in respect of Men whose actions they must direct, howbeit such measures they are as have also their higher Rules to be measured by, which Rules are two, the Law of God, and the Law of Nature; so that the Laws Humane must be made according to the general Laws of Nature, and without contradiction to any positive Law of Scripture, otherwise they are ill made. Ibid. 1. 3. Sect. 9. ${ }^{86}$

Clearly, the civil or human laws of the commonwealth enacted by the legislature must be consistent with the law of nature and Scripture.

After describing the limits of the supreme legislative authority, which cannot rightly exercise any absolute, arbitrary power, Locke states that 'These are the Bounds which the trust that is put in them by the Society, and the Law of God and Nature, have set to the Legislative Power of every Commonwealth, in all Forms of Government'. ${ }^{87}$ Again, both the law of nature and law of God, the latter implying the Adamic Covenant, govern the supreme legislative power and the laws it enacts.

\section{\$20. Christian Obedience and Government}

The New Covenant of Grace requiring both faith and obedience applies to Locke's political society and government. Yet for this commonwealth of Christians, 'faith' is within the province of the church, not civil government. As Locke explains in his Letter concerning Toleration, faith or 'the care of souls is not committed to the civil magistrate, any more than to other men'. ${ }^{88}$ What is highly relevant for politics and government is the second part of the New Covenant: obedience. This is within the jurisdiction of political society and government. The legislative power must enact civil laws that reflect the law of nature and the divine positive law of Scripture, and individuals who are obedient fulfill the second part of the covenant. In other words, civil obedience has

\footnotetext{
${ }^{86}$ Ibid., II. 136, 358.

${ }^{87}$ Ibid., II. 142, 363.

${ }^{88}$ Locke, Letter concerning Toleration, 394.
} 
theological consequences via Locke's covenant theology of faith and obedience. While Locke does not say so explicitly in the Second Treatise, I believe it is an accurate extrapolation of his political theology. If the law of nature has theological grounding, as I have attempted to show, then obedience to it has theological consequences. Locke is clear in the Reasonableness that obedience to the law of nature and law of God are essential for justification or salvation.

Consequently, people who constitute a commonwealth of Christians ought to be the best subjects, because of the theological requirement of obedience. This is not a blind obedience, however, as Locke is clear that it is only civil laws consistent with the law of nature and law of God that obligate us and require our allegiance.

\section{\$21. A Theistic Commonwealth}

A second proposed interpretation of the law of nature as theological in the Second Treatise is a theistic commonwealth-one that accommodates Christians and non-Christians alike. The latter may not believe that the law of nature is restated in the Adamic, Mosaic, and New Covenants in Scripture; but they can or do know that God is its legislator and so that it must be followed. Hence the requirement of theism. How does Locke defend this position? He does not address this as an issue in the Second Treatise; however, he does in his earlier Essays on the Law of Nature (1663-4). Nevertheless, it is evident in the Second Treatise that God is inseparable from the law of nature, whether or not the connection is made with Scripture.

\section{\$22. God as Legislator of the Law of Nature}

The law of nature as reason is not a naturalistic argument, because the law of nature is what God has given us. Beginning with the first sentence of Essay on the Law of Nature I (ELN), in arguing that there is a law of nature, or rule of morals, Locke writes:

Since God shows himself to us as present everywhere and, as it were, forces himself upon the eyes of men as much in the fixed course of nature now as 
by the frequent evidence of miracles in time past, I assume there will be no one to deny the existence of God, provided he recognizes either the necessity for some rational account of life, or that there is a thing that deserves to be called virtue or vice. ${ }^{89}$

Citing Seneca, the Stoics and Aristotle, Locke reiterates the classic understanding of the law of nature as principles of moral virtue and vice according to right reason. Locke says further that 'This law of nature can be described as being the decree of the divine will discernible by the light of nature and indicating what is and what is not in conformity with rational nature, and for this very reason commanding and prohibiting'. 90 The law of nature is 'a law enacted by a superior power and implanted in our hearts', and reason is 'its interpreter, unless, violating the dignity of the supreme legislator, we wish to make reason responsible for that received law which it merely investigates'. ${ }^{91}$ Locke believes God is the legislator of the law of nature, and, as such, 'All the requisites of a law are found in natural law, ${ }^{\prime 2}$ - namely, a superior will, commands and prohibitions, and the creation of a binding obligation. ${ }^{93}$ These passages are cited by scholars claiming Locke is a voluntarist, because of his reliance on God's will. ${ }^{94}$ This is not an issue I can address here, except to say that I agree with Nuovo and others that Locke is both a voluntarist and a rationalist. In making the point that princes are not exempt from the law, Locke

${ }^{89}$ John Locke, 'Essays on the Law of Nature', no. 1, in Political Essays, ed. Mark Goldie (Cambridge, 1997), 81.

${ }^{90}$ Ibid., 82.

${ }^{91}$ Ibid.

${ }^{92}$ Ibid., 82-83.

${ }^{93}$ Ibid., 83.

${ }^{94}$ For an argument that voluntarism is a self-contradictory position that fractures the foundation that Locke posits, see Gary DeHart, 'Fractured Foundations: The Contradiction between Locke's Ontology and His Moral Philosophy', Locke Studies 12 (2012): 111-48. 
says they are subject to the laws of God and nature, because 'Grants, promises and oaths are bonds that hold the Almighty'. 95

In ELN II, Locke states that the law of nature is known by the light of nature, or reason. Without considering the epistemic analysis that follows in ELN II, where Locke argues that knowledge of the law of nature is through sense-experience (the subject of ELN IV), not tradition or inscription (the subject of ELN III), the cardinal point is that God has legislated it:

This law is the will of this omnipotent lawmaker, known to us by the light and principles of nature; the knowledge of it can be concealed from no one unless he loves blindness and darkness and casts off nature in order that he may avoid his duty. ${ }^{96}$

Because God is the legislator of the law of nature, it is universally binding. Locke states in ELN VII that the binding obligation of the law of nature is 'permanent' and 'universal'. Since the beginning, the law of nature has existed. Locke writes that 'The bonds of this law are perpetual and coeval with the human race, beginning with it and perishing with it at the same time'. ${ }^{97}$

Furthermore, it is God's will that binds both the unwritten law of nature and written divine positive law. In ELN VI, Locke writes:

If natural law is not binding on men, neither can positive divine law be binding, and that no one has maintained. In fact, the basis of obligation is in both cases the same, i.e. the will of a supreme Godhead. The two laws differ only in method of promulgation and in the way in which we know them: the former we know with certainty by the light of nature and from natural principles, the latter we apprehend by faith. ${ }^{98}$

\footnotetext{
${ }^{95}$ Locke, Two Treatises, II. 195, 396.

${ }^{96}$ Locke, 'Essays on the Law of Nature', no. 2, 117, 119.

${ }^{97}$ Locke, 'Essays on the Law of Nature', no. 7, 122.

${ }^{98}$ Locke, 'Essays on the Law of Nature', no. 6, 119-20.
} 
The source of obligation is God's supreme will as legislator, which is binding upon all rational creatures.

One might go further still: Locke defines the human species as rational precisely in virtue of its capacity to grasp and follow natural law. Its existence as a moral species is predicated upon God's promulgation of that law. Without it, there would be no human race, in the moral sense, and no political society, civil or religious. Some society, analogous to that of animals, in which sensuality, desire, and force were governing principles, might perhaps be conceivable without theism, but nothing that made human beings distinctively human would be present there: its members would not, for instance, recognise one another as equals and would behave more like beasts than men (as did, apparently, the inhabitants of the instance of such a sub-human society Locke provided in ELN V, the natives of Soldania Bay in Brazil). ${ }^{99}$ For what makes people equal is that they are all equally dependent on God, know that He is the moral governor of every one of them, and have duties to themselves and one another that are common to all of them in consequence of their common subjection to and dependence upon Him.

\section{\$23. Atheists}

It follows from this that Locke has no time for atheists because they are, inter alia, destructive of political society. As Locke writes, 'Belief in a deity is not to be reckoned amongst purely speculative opinions, for it being the foundation of all morality, and that which influences the whole life and actions of men, without which a man is to be considered no other than one of the most dangerous sorts of wild beasts, and so incapable of all society'. ${ }^{100}$ In light of my argument, we can see why Locke deals with atheists so decisively and peremptorily. He says, 'Those are not at all to be tolerated who deny the being of a God. Promises, covenants, and oaths, which are the bonds of human society, can have no hold upon an atheist. The

\footnotetext{
${ }^{99}$ Locke, 'Essays on the Law of Nature', no. 5, 113.

${ }^{100}$ Locke, ‘An Essay concerning Toleration', 188.
} 
taking away of God, though but even in thought, dissolves all' ${ }^{101}$ Thus even though Locke believes magistrates ought not to regulate beliefs, since they are the inward persuasions of the mind, atheists are incapable of entering into the political compact, and therefore cannot be a part of the commonwealth. Atheists stand in violation of the law of nature, and are thus in a 'state of war', unable to obey laws, sustain morality, or be properly human. Locke believed the magistrate may establish theism since it is necessary to maintain the public good. ${ }^{102}$

In sum, the Second Treatise presupposes and lays out the grounds of a theistic commonwealth in which the law of nature acts as the unifying moral force for political society and government. The legislative God of the law of nature can be accommodated to any theistic religion with one caveat - it must be monotheistic. ${ }^{103}$ In the Reasonableness, Locke states that one of the advantages of Jesus Christ coming into the world was to unquestionably establish that there is 'One Invisible True God'. ${ }^{104}$ Locke has the Christian God in mind, not that of any other faith. Still, it is the divine authority of the law of nature that secures the commonwealth by unifying the morality necessary for its existence and continuation. If this fact is

\section{${ }^{101}$ Locke, Letter concerning Toleration, 426.}

102 It is clear in The Fundamental Constitutions of Carolina (1670) that Locke's intent was a theistic establishment. Article Ninety-Five of the Fundamental Constitutions referring to slave states says that 'No man shall be permitted to be a freeman of Carolina, or to have any estate or habitation within it, that doth not acknowledge a GOD; and that God is publicly and solemnly to be worshipped'. John Locke, 'The Fundamental Constitutions of Carolina', in The Works of John Locke (10 vols., London, 1823), X, 193. The nature and extent of Locke's constribution to this document remains a matter of debate.

${ }^{103}$ Polytheistic religions are a minority worldwide, as Hindus (the largest group of these) comprised $15 \%$ of the population in 2010 and are expected to maintain that percentage in 2050. Pew Research Center, The Future of World Religions: Population Growth Projection 2010-2050 (Washington, D.C., 2015), 6.

${ }^{104}$ Locke, Reasonableness, 145. It might be argued that monotheism is not required politically in the same way that Christianity is not. At a minimum, theism is necessary, and while polytheism could present a problem if different deities posited conflicting laws of nature, I assume with the Locke of the Second Treatise that the law of nature issued by God is the same everywhere. 
thought to be sufficient to denude Locke's arguments of relevance to the world in which we live today, it may be worth reminding readers that the majority of the world's population is theistic. According to the Pew Research Center, in 2010 only $16 \%$ of the world's population were categorized as atheist, agnostic, or of no particular religion. ${ }^{105}$ In the United States, by 2014 the population of Christians had declined from $78.4 \%$ (2007) to $70.6 \%$, and $22.8 \%$ were categorized as atheist, agnostic, or of no particular religion. Importantly, only $3.1 \%$ of that figure were atheist. ${ }^{106}$ In Locke's time, the percentage of atheists would be miniscule compared to today; nevertheless, my point is that the vast majority of the world are theists, and a majority are Christian. ${ }^{107}$ As indicated above, the percentage of Christians is much higher in the United States.

Christianity and theism are not what separates Locke's world from today. Rather, it is the loss of the law of nature and its theological connection to reason. What makes Christianity or other religions politically ineffective or dangerous is the missing foundation of reason, without which they are reduced to expressions of personal preference or exertions of will. Locke's law of nature as theological provides a safeguard to the potential irrationality of reason or religion - either acting alone will not suffice. Universal reason is the law of nature allowing the transcendence of God to mediate politics indirectly by furnishing a moral foundation. The two must be connected: God and reason. Differences and disagreements about politics will not end when they are, but Locke tells us that what is fundamental or foundational is globally available from the source of all that is

${ }^{105}$ Pew Research Center, The Future of World Religions, 5-6.

${ }^{106}$ In 2007 , only $16.1 \%$ of the population were atheist, agnostic, or not affiliated with a particular religion (rising to $22.8 \%$ in 2014). The number of declared atheists increased over this period from $1.6 \%$ to $3.1 \%$, but the largest share $(15.8 \%)$ of the $22.8 \%$ were unaffiliated. Pew Research Center, America's Changing Religious Landscape (Washington, D.C., 2015), 4.

${ }^{107}$ According to the Pew Research Center, in 2010, 31.4\% of the world's population were Christian and 23.2\% Muslim, but by 2050, the gap between Christians and Muslims will close, with $31.4 \%$ and $29.7 \%$ respectively. Pew Research Center, The Future of World Religions, 6. 
political - God, who has given the law of nature to mankind to enable them to live well with their neighbors as they go about His business.

\section{\$24. Conclusion}

Locke is claiming a political foundation that is singular and universal - the law of nature. As reason, the law of nature is at a minimum theistic, and at best, Christian covenantalism. In either case, universal natural reason as the basis of politics transcends moral or cultural relativism. And this claim is something to consider seriously even today.

Marymount University 